\title{
Measuring Business Performance: Emerging Perspectives Of The Balanced Scorecard
}

Robert McGinty, (Email: rmcginty@ewu.edu), Eastern Washington University

\begin{abstract}
Benchmarking business performance over time is an emerging managerial capability that is used for continuous improvement of existing value adding activities and processes that become leading indicators of strategic success. To achieve this success, corporations first define success, and then they decide how to get there from where they are presently. Financial information has long been the language of business with accountants adding up the numbers and defining success in bottomline figures. What have been missing are the non-financial elements of business enterprises, elements that can be quantified and linked to the bottom line as predictors of financial success. This paper utilizes Kaplan \& Norton's Balanced Scorecard (BSC) and an extensive pilot study of ski resorts to explore an awareness of using non-financial information as a supplement to financial information in explaining overall strategic performance in one segment of the tourism industry.

Leading and lagging indicators of a non-financial nature were used in the study to help focus on the strategic and operational management practices at selected ski resorts in Colorado, Montana, Canada, and the Pacific Northwest. A list of potential critical success factors and non-critical success factors that help build value and best business practices for ski resort management, were identified through written and oral interview survey techniques following a combination Delphi \& Nominal Group Techniques. Previous work on the balanced scorecard by Kaplan and Norton aided in the identification and description of indicators within each of four balanced perspectives. Recognition of the intuitive elements of non-financial measures represents a departure from prevalent theory that favors the more traditional financial perspective.
\end{abstract}

\section{Introduction}

Alice asked, "Would you tell me, please, which way I ought to go from here?" "That depends a good deal on where you want to get to," said the Cat. "I don't much care where..." said Alice. "Then it doesn't matter which way you go," said the Cat. "...so long as I get somewhere," Alice added as an explanation, "Oh, you're sure to do that," said the Cat, "if only you walk long enough."

Lewis Carroll, Alice in Wonderland

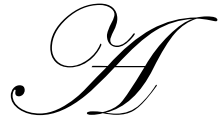

pilot research study (this author, et al 2001) utilized a framework incorporating cause and effect relationships in an if-then-contingency statement format using non-financial leading processes and activities to query perceptions of ski resort managers concerning how they attempt to continuously improve long-run outcome measures of financial performance. The focus of the study centered on three primary questions. First, do ski resorts have a list of short and intermediate run non-financial performance objectives that they see correlated to long-run financial performance? Second, do ski area managers agree that non-financial performance measures are an important aspect of strategic planning? Third, do the core perspectives of the balanced scorecard developed by Kaplan and Norton (1992, pp. 128-130) improve top management's ability to explain and predict long-run strategic performance? 


\section{What is the Balanced Scorecard?}

The scorecard balances traditional financial measures with non-financial measures. Both combine to tell the story of past business practices and events that help create value, leading to bottom line outcomes. BSC helps shed light on the use of operational performance measures as strategic planning aids for practicing consultants and top-level ski resort managers. It is a technical tool to help managers focus on core values and core competencies. It focuses upon operational measures of performance and processes believed to be leading indicators of long-term success as defined in vision statements or articulated using strategic goals and objectives. Ideally, there is a predictive correlation between the leading and lagging measures, where one set of indicators leads or predicts to another set of bottom-line financial indicators of success or failure. The challenge for management is to become aware of the value chain of cascading operational processes that are the true conduits leading to success, as defined by measurable financial and non-financial goals and objectives. In a sense, coincidental correlations between leading and lagging indicators are established enabling management to monitor operational processes and hence influence strategic results. Thus, management can monitor, measure, benchmark, and orchestrate changes during short and intermediate runs to affect the long-run outcomes reflected in the bottom-line. This management approach will help achieve higher levels of performance, thereby helping a firm improve or secure a competitive advantage.

The balanced scorecard is part of a strategic management process that forces management to articulate corporate visions, goals, objectives, and the strategic means to achieve them. It forces management to define in measurable terms the means to achieve ends, thereby translating vision and strategies into implementation action plans. Managers must decide which numbers matter while being aware that, "Not everything that can be counted counts, and not everything that counts can be counted" (Albert Einstein). And, much like an accrual accounting system, BSC provides feedback about how well internal operational processes and long run outcomes are trending in the short run, thereby enabling management to intercede and continuously modify and improve performance. It is similar to the role of the captain of a large passenger ship who checks the ship's position and makes navigational corrections to ensure that the ship is kept on its charted course in order to reach its destination on time following the most efficient route. Ideally, management monitors business performance measures, orchestrating changes to enhance efficiencies and effectiveness of operations that affect strategic outcomes.

BSC is a way of linking a firm's future visions to short and intermediate-run objectives and measures of performance that are used as "an informing and learning system to help mid-managers understand how the firm creates value and achieves its strategic goals. Common sense suggests that organizations would be more effective doing more of the 'right' things a little wrong than the 'wrong' things entirely right. "Reliable performancemeasurement systems, such as BSC, focus an organization's attention on the 'right' things" to monitor" (McMann \& Orlando, 1998, p.12). Measures might include, but are not limited to, time, especially speed at which products are brought to market, quality, efficiencies, customer responsiveness \& satisfaction, reliability, costs, growth \& economic development, shareholder wealth \& value, revenue growth \& rates, margins, market share, capacity \& its utilization, value creation activities \& long-run results, and reducing complexities that hinder effective or efficient value adding activities and processes. Such critical success measures will be both financial and non-financial in nature.

Companies can and should use the BSC as a strategic planning \& control technique to clarify purpose, vision, and mission as well as to determine goals to achieve and how to achieve them. The fundamental challenge is to measure both the outcomes and the inputs, and to establish leading-lagging relationships for control and monitoring purposes so necessary for effective and efficient management practices. "The scorecard should translate the business unit's strategy into a linked set of measures that define both the long-term strategic objectives and (explain the) mechanisms for achieving those objectives" (Kaplan \& Norton, 1966, pp.10-11). The argument is made that as continuous improvements are made within operational processes the bottom-line financial outcomes will take care of themselves. In other words, all actions have consequences, and theoretically, both the actions and the consequences can be measured, monitored, controlled, and maximized. Will business practitioners within the snow industry take advantage of these relationships to improve their bottom lines by following Balanced Scorecard theory and utilize its four major perspectives? This research explores realities and answers to that central question. 


\section{Innovation and Learning Perspective}

The Innovation and Learning perspective of the BSC represents the capabilities of the collective individuals of an organization complete with the state of available technologies or what Kaplan and Norton (1992, p.70) call, "a company's ability to innovate, improve, and learn (which) ties directly to the company's value (or worth)." This segment of the scorecard is viewed as non-financial and includes employee capabilities \& training as well as synergetic innovations and innovative capabilities achieved through structural and cultural changes. It encompasses the notion of both employee empowerment and that of a learning organization where human resources are the main repository of knowledge. Employees must have opportunities for improvement through training and development programs in order to be on the cutting edge, or at least recognize where the cutting edge is located. This type of learning organization includes more than training per se. Measures might include length of employee tenure, employee education, and knowledge, loyalty of employees, training opportunities provided and accepted as determined by employee participation, turnover, absenteeism, and job or pay satisfaction, to name but a few important measures of performance. "Studies show that a significant part of an organization's profitability is linked to the quality of its work life, which is based largely on trust and loyalty both within the organization and with outside people such as customers and suppliers" (Cooper, 1997, p.32). Hence, managers can build trust and loyalty knowing that organizational success generally improves as a result. In an April 2001 survey by the Information Technology Association of America, "hiring managers prized loyalty and people skills above all other desirables in new employee" (Johnson, 2001, p.16).

\section{Internal Business Processes \& Operations Perspective}

The second BSC perspective, Internal Business Processes \& Operations, is derived from the application of the innovations and learning perspective resulting in improved operational processes that continuously lead to improved efficiencies in effectively producing goods or services expected by a firm's customer segments. These operations and processes help build value through the applications of technologies and capabilities such as supply chain management, six sigma, TQM, ISO 9000 and the like. Measures such as the number of new ideas or suggestions adopted, level of production costs, time required to produce a product or provide a service, and the cost of raw materials are also good examples of Internal Business Processes \& Operations.

\section{The Customers' Expectations Perspective}

The third perspective, Customers' Expectations, includes customer concerns of time, quality, performance, and follow-up service. Customer satisfaction is achieved when customer expectations are met. The importance of fulfilling customer expectations to retain loyalties is closely tied to, and predictive of, bottom line results. If one's customers are not satisfied, they will become someone else's customers. Measures of customer satisfaction can be taken directly through surveys or indirectly through tracking repeat sales information, measures of customer loyalty such as repeat sales or visits, market share, number of new customers, and so forth. Kaplan \& Norton (1992, p.70) write, "specific performance measures (can) be derived from customer goals (expectations)." For example, retailing research has linked consumer perception of service experience to perceptions of customer satisfaction regarding quality and loyalty issues (Lambert \& Lewis, 1983, p.50; Fisk, et al, 1993, p.61). Hence, if managers monitor and control the kinds of services their company provides, this will affect customer satisfaction, future sales, and hence the bottom-line.

\section{The Financial Perspective}

Financial measures constitute the fourth and final perspective. This perspective is composed of the traditional bottom-line financial numbers such as ROI, revenue per employee generated, earnings per share, cash flow, liquidity ratios, leverage ratios, activity ratios, profitability ratios, and so forth. Ultimately, all things in business lead to bottom-line financial measures; however, to get there from the start-up position, one has to go through non-financial operational processes involving people and their intangible capabilities. These intangibles are sometimes difficult to conceptualize, observe, measure, understand, and monitor. Yet, techniques have been developed to aid managers with these observations, measurements, and understandings. BSC is one such technique, 
a technique that must be well thought-out and implemented, and, must continuously be supported by top management.

\section{How to Put BSC Theory into Practice?}

The steps to follow in implementing BSC include: (a) defining key performance indicators for your company, both leading and lagging financial and non-financial measures, thus making it easier to analyze the past and forecast the future, (b) monitoring company performance profiles to gain further understanding of how your firm creates value, (c) checking your numbers periodically, and if they are out of 'whack,' interceding and making changes, and (d) understanding that a firm's key performance indicators may vary from one firm to another even within a given industry; however, within an industry considerable commonality should prevail. The idea behind tracking performance measures is similar to staying awake while driving down a busy street. Staying awake at the wheel of one's car or at the helm of one's business helps that person stay on course. Such monitoring provides performance-feedback-information that shape management "perspectives" about gaining competitive advantage. It helps managers identify best business practices to follow within their industry and within their unique productmarket niche. These best or better business practices are critical to a firm's success. The challenge, of course, is to separate out the best practices from the not-so-good practices. Do managers really know their business, their best business practices, and can they measure and monitor them? Hopefully they already can and do; however, if not then BSC will force management to consider these important elements of strategic thinking and strategic planning.

The balanced scorecard enables a contingency statement model of cause(s) and effect(s) to be linked, thus enabling managers to 'tinker' with leading indicators of performance to bring about desired changes in lagging performance measures, i.e., a mechanism using feedback from various records kept to help achieve continuous improvement over time. It is similar to what-if simulation game theory. BSC links employee capability and training, internal business operations, customer responsiveness, and financial performance. Kaplan \& Norton, (1996, p.10) write cogently about the basic premises of BSC, stating, "The scorecard retains an emphasis on achieving financial objectives, but also includes the performance drivers of these financial objectives (measuring) performance across four balanced perspectives: financial, customers, internal business processes, and (the) learning and growth of employees (and hence the learning, growth, and financial success of the corporation)." In a sense, the measures of performance are "balanced between outcomes resulting from past efforts and the measures that drive future performance(s)" (Kaplan \& Norton, 1966, p.10). It is a technical tool used to benchmark a firm's past numbers so that management can "Beat Yesterday's Ledgers" (Magarette, 2002, p. 189).

\section{The Performance Numbers Game}

Robert Eccles (1991, p.131) writes, "The numbers accounting systems generate often fail to support investments in new technology and markets essential to successful performance." He stressed the importance of using non-accounting information to compare and improve performance, using for example, quality or customer satisfaction measures. In a similar vein, Ittner and Larcker (1998, p.2) boldly state, "Non-financial measures . . . may be better predictors of future financial performance than accounting measures." Their concern is that present accounting measures of performance are less than fully adequate to maximize the utilization of scarce resources of the firm. The point to be made here, of course, is the need to separate fact from fiction and hype from good faith intent whenever reporting the numbers. The disparate impact of well-intentioned record keeping aside, is it possible to identify and measure the several critical success factors or leading indicators of future success as measured financially or non-financially? Research, theory, and logic seem to suggest that it is entirely possible to benchmark that which must be counted to help firms realize their full potential and gain competitive advantage, build shareholder wealth, and maximize the utilization of scarce resources in the efficient creation of value for their customers.

\section{Key Performance Indicators}

An excellent way for visual learners to conceptualize these causal relationships is with flow charts that link sequential steps leading to predetermined goals or objectives. Essentially, the key performance indicators (KPI) 
translate a firm's vision into a set of measurable strategic and tactical goals and objectives that ebb and flow over time. Top management could then use the indicators to monitor how a firm is doing by pinpointing operational activities and processes that should be tweaked to improve productivity. Hence, managing with the use of critical KPI's becomes a controlling and planning process for management to coordinate the utilization of scarce human and non-human resources, i.e., tangible and intangible assets.

Specific objectives and measures are derived from the firm's vision, philosophy, expectations of stakeholders, and mission statements by management using the firm's tangible assets, intangible assets, and innovative capabilities to their fullest. BSC, using KPI's, requires strategic planners "to capture the essence of the organization's critical value-creating activities" (Chow, 1997, p.21), to define them in measurable terms, and to devise ways of benchmarking changes in both key performances and desired critical outcomes to help monitor and control from a strategic prospective. It is an opportunity for management to consider how value is created, how success will be recognized, and what is required to get from where they are to where they want to be over time, as measured financially and non-financially.

Feedback systems providing timely on-going measures of key areas of performance enable top-level managers to link causes of value creation to the actual bottom-line performance. The challenge is to decide what should be measured and how to measure it. Chow (1997) writes, "Once the overall business process is identified, along with its goals and objectives, it should be possible to identify and rank the measures believed to capture the essence of the organizations' progress toward those goals and objectives." These decisions are tied both to understanding the firm's business and business practices, and in coming to know how well the firm is doing or how it might do better using several WOTS-UP's analysis in different sequential time intervals.

\section{Who is doing What with BSC?}

A growing number of corporations have implemented BSC, including Amoco Corp., J.P. Morgan, HewlettPackard, Aetna, Merck, Sears, Northern Telecomm, MCI Communications, Electronic Data System, Xerox, Mobil, Cigna, Brown \& Root Engr., Monsanto, AT\&T, Advanced Micro Devices, FMC, Metropolitan Life, Mobile Oil, and Goodrich to name a few. Yet, it isn't clear the extent to which top-level managers value the usefulness of BSC. In short, is BSC another fad or will it become a generally accepted strategic practice? Shields (1997, p.22) writes, "institutional theories predict that organizations want to give the external appearance of having implemented new management systems (e.g., ABC, cost of quality, balanced scorecard) in order to appear modern, rational, efficient and legitimate." Apparently then, "using" the BSC does not necessarily mean it is being well used!

Kaplan (1994, p.15) states, "the Balanced Scorecard has the capability of integrating long-range strategic plans with short-term measurable objectives," enabling top management to establish linkage between strategic longrange plans and intermediate range budgeting measures. The ability to measure is the challenge that follows the insightfulness required to identify what to measure. Equally challenging is the process of differentiating between leading vs. lagging indicators of performance in the short, intermediate, or long runs. Successful managers are able to separate fact from fiction, and cause from effect, which may help explain why they are successful. What is their secret?

One popular competitive practice in retailing is "the utilization of technology as a means to achieve efficiencies by reducing time or costs, and thus enhance customer satisfaction" (Lusch, et al, 1993, p.5). While there appears to be nothing new here, the cost of acquiring this new technology may over shadow preliminary, short-run efficiency gains. Yet, Cisco has developed software enabling virtual accounting systems with real time financial reports generated on a daily basis. Cisco has decreased the time and costs required for streaming financial data in real time, using corporate hardware systems and the new software. The same streaming of non-financial data can be accomplished using, for example, PLM software developed by the consulting firm AMR Research (Bartholomew, 2003, p.29).

"Questions about the relevance of accounting information have generated interest in the use of nonfinancial information to improve performance measurement and decision-making. Research to date, however, has 
produced only limited evidence of economic benefits from the use of non-financial measures. The reason for this may be due as much to a firms' inability to implement performance-measurement systems that include nonfinancial measures as they depend on the value of the non-financial information itself' (Smith, 2000, p. 53).

\section{An Illustration of BSC: “Snow Industry Pilot Study of Select Ski Resorts” (This Author, 2001)}

The data for the analysis of a pilot study consisted of responses to a survey instrument (see Appendix) by ski resort personnel from thirty randomly selected ski resorts located throughout Canada and the western region of the United States. The survey was conducted via telephone interviews with each ski resort respondent asked to respond to approximately forty questions. The results of the survey were compiled and analyzed utilizing a one-way analysis of variance and a Tukey-Kramer procedure. The analysis of variance was conducted at the .05 level of significance with the responses grouped into one of the four major perspectives of the BSC. Two hypotheses were tested with the sample data:

Ho: There is no significant difference among the mean ranking of the four BSC Perspectives.

H1: There is a significant difference among the mean ranking of at least one of four major BSC Perspectives.

The test results indicated a 'p' value of .000 . Since the 'p' value of the test was less than the .05 level of significance, the null hypothesis was rejected. There was a statistically significant difference among the means of the four groups; therefore, the Tukey-Kramer test was conducted to evaluate which of the means differed significantly from each of the others. The Tukey-Kramer test indicated that the importance of finance factors in the perspective of ski resort managers differs from their perspectives of or feelings of importance of the factors making up the customers and employees perspective segments of the BSC. However, finance did not differ significantly from the internal business practices perspective. The majority of ski resort managers involved with this pilot study do not seem to either understand or accept the strategic accounting approach to managing as developed by Kaplan and Norton within their Balanced Scorecard. Thus, a number of ski resort managers appear to be engaged in a sort of self-fulfilling prophecy that the industry is changing from a popular and profitable snow recreation industry into a land development business where real estate is the financial driver of the bottom line successes. They seem to believe that, while money is not the only hallmark of success, it is way ahead of whatever is in second place.

\section{Limitations}

The survey had certain limitations because contacting individual respondents proved to be very time consuming and somewhat rushed. It occurred during the "high season" for the Snow Industry, and resort managers sometimes referred the survey team to one of their subordinates. Not all of the respondents, then, had identical positions or experiences with the industry or with making strategic-related decisions. The results of the study suggest that financial perspectives are significantly related to the general ski manager's overall strategic decisions. However, the non-financial categories are not so clear-cut. For example, ski resort managers should have been able to create contingency statements as a means for them to better communicate their priorities and critical success factors as benchmarks in order to enhance the bottom line. One example of communicating such a contingency might be, "IF the time spent in getting from the parking lot onto a ski slope is less than 20 minutes, THEN skiers will be satisfied, THEREFORE they will enjoy themselves, spend more money, tell their friends about the ski area and CONSEQUENTLY, enhance the bottom line of the ski resort" (This Author et al, 2001). Hence, time as a measure of performance for the efficiency of a ski area's operations can be monitored, controlled, and improved leading to improved customer satisfaction. This way of strategic thinking, using time as a performance measure seems reasonable, since customers are extremely important stakeholders, and, since ski resort customers seem to want instant, i.e., timely, gratification as part of what it takes to satisfy them. The majority of the ski resort managers contacted were well aware of the importance of 'queuing-line' waits of skiers waiting in lift lines; however, time spent in line at the food counter was not deemed to be of much importance in achieving visitor satisfaction and hence profit over time of repeat visits. Additionally, few area managers seem to connect visitor satisfaction with the kinds and variety of evening activities for children and young adults. 


\section{Management Practices}

A key requirement for management is to work together to clarify their own organization's corporate reality in creating or adding value to inputs to produce the desired outputs demanded by stakeholders. Good strategies evolve from precise planning, itself a product of standards of control used to monitor performance over time. This is a deceptively simple notion but one that few top-level ski resort managers seem to have mastered. Perhaps, it is the difference between leaders, or what Luthan and Lockwood (1984, p.117) categorized as "real managers" versus nonleaders. For every Jack Welsch or Warren Buffet there are no doubt hundreds of "who is s/he?" How many of the latter work at ski resorts might be an interesting follow-on study.

"Top industry performers balance financial and non-financial measurement, link strategic measurements to operational ones, and have measurement standards that their employees understand (and accept while avoiding) the activity trap (of) too many measures" (Lingle \& Schiemann, 1996, p.56). "Real leaders" (Luthans \& Lockwood, 1980, p.122) avoid too many measures and avoid goal displacement while non-leaders fall into the 'trap', perhaps to the detriment of the overall strategic performance of the firm. The study did not investigate the degree of risk-taking of our sample of ski resort managers. Successful managers and leaders must take risks knowing that the window of opportunity is located directly above the trapdoor of doom. As Catherine \& Joe Stenzel (1997, p.3) write, "Make no mistake. Strategic performance measurement work is not for the faint of heart. This work takes great courage. It is hero's work, and we do not use the term hero lightly or romantically." In fact, it is much more than hero's work; it is also "shero's" work as well, where women are equal contributors to bottom-line successes. (Coincidentally, all the resort managers surveyed were white males!)

\section{Reflections on the Three Primary Focus Questions}

The primary focus of the pilot study centered on four primary questions. First, are ski resort managers familiar with BSC? Secondly, Are ski resort managers implementing BSC? Third, who is doing what with BSC? Fourth, will business practitioners within the snow industry take advantage of these relationships to improve their bottom lines by following Balanced Scorecard theory and utilize its four major perspectives? The (tentative) interpretation of the results from our pilot study were encouraging. First, a majority of ski resort managers (as high as $80 \%$ ) did not have a preferred list of short or intermediate run non-financial measures of performance that they perceive were linked to long-run financial success with certain budgetary cost overruns being the exception. Second, ski area managers tend to focus on levels of customer satisfaction based on numerous surveys taken at the ski areas, while overlooking the role of a wide array of employees not in direct contact with customers such as service staff, operations personnel, and parking attendants. Third, ski resort managers generally did not seem to accept the core perspectives of the balanced scorecard. Further research is required to shed light on this phenomenon. Perhaps a number of resort managers simply lack the academic training and awareness of strategic management issues and theories.

\section{Summary \& Concluding Comments}

Clearly, finding the right measures of performance to monitor is a crucial challenge for strategic managers and decision-makers. These will become the best business practices for benchmarking and goal setting in order to beat yesterday's numbers and those of key competitors. Results from the pilot study of ski resorts suggested that ski resort managers do not seem to recognize any correlation between operational performance and strategic outcomes. Moreover, ski area managers agreed that several of these important operational performance measures were nonfinancial in nature but of limited significance. Finally, the pilot study needs to be replicated using a larger sample with precise data that is more proprietary in nature. Such information may be extremely difficult to obtain, however.

More field research and validation remains prior to establishing a solid BSC-type of theoretical formula for operating ski resorts. The BSC of Kaplan \& Norton does illustrate causal, sequential chains of activities and processes depicting ways a ski resort might create value for their major stakeholders. Yet, something seems to be missing or amiss. Perhaps, it is the subjectivity in measuring non-financial indicators? Perhaps, it is also a 
misunderstanding by certain managers as to what constitute best business practices, or, it may be their inability to recognize critical success factors for their industry and organization.

"As organizations, environments and organizational accounting (systems) change, concurrently there will be dramatic changes in the demands for (various) types and quantities of information. The demand for non-financial information will obviously increase (and) there will be (a growing) demand for new kinds of financial information" (Shields, 1997, p.22). This 'virtual accounting' has taken place at Cisco through the efforts of Larry Carter, CFO of Cisco Systems (de Myer, 2001, p.56). Real time feedback from Cisco's "virtual-close financial reporting system (enables them) to pull off near-real-time financial reporting (and) react more quickly to changes in the marketplace," according to Desiree de Myer.

The challenge for management then is twofold, (a) to identify valid and reliable measures of performance, and (b) to determine how best to collect and utilize this information to fine-tune their organization's operations. Briefly, the challenge is to decide what to measure and how to measure it in a timely fashion. The usefulness to management of performance measurements is to assist in fulfilling the expectations of stakeholders both internal and external. The balanced scorecard appears to be a useful strategic feedback system when properly utilized. The road to perfect strategic decision-making, however, is still under construction.

\section{Appendix}

\section{Telephone Questionnaire}

The idea behind this telephone survey involved asking a selected sample of ski area managers what (conceptually) they consider important benchmarks for managing ski areas, rather than trying to simultaneously get a hard and fast dollar or other quantitative measure of the concept(s). For example, they may be very interested in employee learning. Thus, they may frequently think about it and subjectively evaluate it, but never count the number of new employee ideas. The items below are a short set of measures that ski area managers may perceive as important, with no attempt at making them easy to quantify.

The survey was implemented without mentioning the bold face category titles, although we used them when tabulating the results. The survey team contacted ski resort managers and began the interview by first asking, "what indicators do you use when comparing your ski resort operations with other ski resorts." Then, depending upon the response, the team member went directly to that specific category.

"Please estimate how important you think the following items are in making business decisions on a scale of one to five with five being the most important."

\section{Financial Perspectives}

$\begin{array}{ll}\text { - } & \text { Total revenue/sales } \\ \text { - } & \text { Number of skier visits per day } \\ \text { - } & \text { Net Income } \\ \text { - } & \text { Cash Flow } \\ \text { - } & \text { Visitor count per skier days } \\ \text { - } & \text { Real Estate sales by number of units and revenue } \\ \text { - } & \text { Seasonal/alternative uses of facility year-round } \\ \text { - } & \text { Monitor what other ski areas are doing }\end{array}$




\section{Customer Expectations Perspective}

- $\quad$ Customer loyalty

- $\quad$ Daily ticket sales

- $\quad$ Number of complaints

- $\quad$ Employee-customer interactions

- $\quad$ Parking availability

- $\quad$ Customer satisfaction surveys

- Recognizable "Village Base Area"

- $\quad$ Adequacy of Base Lodging

- Daily snowfall

- Number of advanced bookings

- Number of inquires about local real estate

- Number of repeat ski customers

- $\quad$ Number of complaints

\section{Internal Business Processes \& Operations Perspective}

- $\quad$ Quality of vendor services

- $\quad$ Uphill lift capacity per hour

- Monitor Snow Industry Innovations

- $\quad$ Queuing lines

- Average time from parking car to ticket office to lift line

- $\quad$ Average time spent in lift line

- Monitor industry practices (please specify how done)

\section{Employees: Innovation \& Learning Perspective}

- Ways to improve employee performance

- $\quad$ Team building

- Loyalty of employees to organization

- $\quad$ Employee tenure/seniority

- $\quad$ Number of grievances filed

- $\quad$ Number of employee ideas implemented

- $\quad$ Salesmanship or interpersonal skills of employees

- $\quad$ Employee treatment of ski area customers

- $\quad$ Mountain Hosts and their daily reports

- $\quad$ Cultural diversity

- Work environment

- Quality of work life

\section{Thank you for your help in completing this telephone survey!}

\section{References}

1. Bartholomew, Doug, "Design and Conquer," CFO, May 2003, p. 29.

2. Chow, Chee, et al, "Applying The Balanced Scorecard to Small Companies," Management Accounting, August 1997, pp.21-26.

3. Cooper, Robert, "Applying Emotional Intelligence in the Workplace," Training \& Development, December 1997, p. 32. 
4. De Myers, Desiree, "Speed Up Financial Reporting," Smart Business: Technology at Work, May 2001, p.56.

5. $\quad$ Eccles, Robert, "The Performance Measurement Manifesto," Harvard Business Review, Jan-Feb 1991, p. 131-137.

6. $\quad$ Fisk, et al, "Tracking the Evolution of the Services Marketing Literature," Journal of Retailing, Vol. 69, No.1, 1993, pp.61-104.

7. Henry, David. "The Numbers Game" Business Week, May 14, 2001, p. 100.

8. Ittner, Chris and David Larcker, "Are Non-financial Measures Leading Indicators of Financial Performance: An Analysis of Customer Satisfaction," Journal of Accounting Research, Vol. 36, 1998, pp.1-35.

9. Johnson, Carrie, “Jack of all trades or master of one?” Spokesman Review, September 9, 2001, p.16.

10. Kaplan, Robert \& Norton, David. "The Balanced Scorecard: Measures that Drive Performance, Harvard Business Review, No 70, Jan-Feb, 1992, pp70-79.

11. Kaplan, Robert, "Devising a Balanced Scorecard Matched to Business Strategy," Planning Review, SeptOct, 1994, p. 15.

12. Kaplan, Robert \& Norton, David. The Balanced Scorecard: Translating Vision into Action, Harvard Business School Press, Boston, 199, pp.10-11.

13. Kurtzman, James. "Is your Company Off Course?” Fortune Magazine, Vol. 135, February 17, 1997, pp. 128-30.

14. Lambert, et al, "Managing Customer Service to Build Market Share and Increased Profit," Business Quarterly, Vol. 48, Fall, 1983, pp.50-57.

15. Lingle, John \& William Schiemann, "From Balanced Scorecard to Strategic Gauges: Is Measurement Worth It?," Management Review, vol. 85, No. 3, March 1996, p.56.

16. Lusch, R.F., et al. Retail Marketing, Cincinnati: South-Western Publishing, 1993, p.5.

17. Luthans, Fred \& Diane Lockwood, "Toward an Observation System for Measuring Leader Behavior in Natural Settings," in Leaders and Managers, New York: Pergamon, 1984, p.122. Also, see Real Managers by Luthans.

18. Magretta, Joan, What Management Is, Free Press, New York, 2002, p. 189.

19. This Author, Roy Regal, \& Steve Gady, "An Exploratory Study of Ski Industry Use of the Balanced Scorecard, Proceedings of the Applied Business Research Conference, Cancun, Mexico, March 2001.

20. McMann, Paul \& Joe Orlando, "You May Need New Performance Measures When...," Journal of Strategic Performance Measurement, Vol. 2, No. 1, Feb-Mar 1998, p.12.

21. Shields, Michael, "Research in Management Accounting by North Americans in the 1990's," Journal of Management Accounting Research, vol. 9, 1997, p.22.

22. Smith, Rodney. Explaining Relative Firm Performance in the Personal Computer Manufacturing Industry: A Balanced Scorecard Framework. Dissertation, University of California, Irvine, 2000, Professor William F. Wright, Chair, pp.53-57.

23. Stenzel, Catherine \& Joe, "From the Editors," Journal of Strategic Performance Measurement, Vol. 1, No. 5, Oct-Nov 1997, p.3. 